\title{
高速液体クロマトグラフィーによる食肉中のキタサマイシン 及びジョサマイシンの定量
}

\author{
堀江 正一袖, 斉藤 貢一 ${ }^{*}$, 中澤 裕之 ${ }^{* *}$
}

\section{Determination of kitasamycin and josamycin in meat by HPLC}

\author{
Masakazu Horie, Koichi Saito* and Hiroyuki NAKAZAwA ${ }^{* *}$
}

\author{
* Saitama Prefectural Institute of Public Health, 639-1, Kamiokubo, Urawa, Saitama 338 \\ ${ }^{* *}$ Hoshi University, 2-4-41, Ebara, Shinagawa-ku, Tokyo 142
}

(Received 22 July 1996, Accepted 9 September 1996)

\begin{abstract}
A simple and rapid method using HPLC has been developed for the determination of macrolide antibiotics, kitasamycin and josamycin in animal tissues. Kitasamycin comprises several components: leucomycin $A_{1}, A_{3} \sim A_{9}$ and $A_{13}$. Josamycin is identical to leucomycin $\mathrm{A}_{3}$. The drugs were separated on a Puresil $5 \mathrm{C}_{18}$ column $(150 \times 4.6 \mathrm{~mm}$ i.d.) with $0.05 \mathrm{M}$ phosphate buffer $(\mathrm{pH} 2.5)$-acetonitrile $(58: 42)$ as the mobile phase at a flow rate of $0.5 \mathrm{ml} / \mathrm{min}$, and detected at $232 \mathrm{~nm}$ with 0.04 AUFS. The drugs were extracted with $0.3 \%$ metaphosphoric acid-methanol $(7: 3)$, and the extracts were cleaned up on a Bond Elut SCX (500 mg) cartridge. The calibration graphs were rectilinear from 5 to $100 \mathrm{ng}$ for kitasamycin and josamycin. The recoveries of the drugs from various animal tissues fortified at a level of $1.0 \mu \mathrm{g} / \mathrm{g}$ were $76.8 \sim 91.5 \%$ with high accuracy. The detection limits were $0.05 \mu \mathrm{g} / \mathrm{g}$ for both drugs. By selecting the proposed methods using HPLC, the individual components of kitasamycin are can be quantitatively determined with speed, ease and accuracy.
\end{abstract}

Keywords : residual analysis; kitasamycin; josamycin; veterinary drug; HPLC.

\section{1 緒言}

家畜の疾病予防と治療を目的に数多くの抗菌性物質 (抗生物質及び合成抗菌脷) が用いられ，畜産物の生産 性向上に大きく寄与している. しかし，一方ではこれら 医薬品の畜産物への残留が食品衛生上強く懸念されてお り，畜産食品の安全性を確保するために残留規制が行わ れている．従って，抗菌性物質の残留の有無を確認する 迅速で精度の高い分析法が必要とされている1).

* 埼玉県衛生研究所: 338 埼玉県浦和市上大久保 639-1

** 星薬科大学: 142 東京都品川区荏原 2-4-41
キタサマイシン (KT) 及びジョサマイシン ( JM) は, 16 員環のラクトン環を基本骨格とするマクロライ ド系抗生物質 (MLs) で, グラム陽性菌やマイコプラ ズマなどに強い抗菌力を示し, 肺への移行性に優れてい ることから呼吸器感染症治療薬として多用されている. 一般に, MLs は化学構造が類似した複数の成分の混合 物であり，KT では医薬品となった最終的精製段階にな っても, ロイコマイシン $\mathrm{A}_{1}, \mathrm{~A}_{3} \sim \mathrm{A}_{9}, \mathrm{~A}_{13}$ 等の多数の 成分 (Fig. 1) を含んでいる2). しかし, 現在のところ, KT 中の各成分を定量する方法は報告されておらず, 「飼料及び飼料添加物の成分規格に関する省令」 ${ }^{3)}$ の中で 


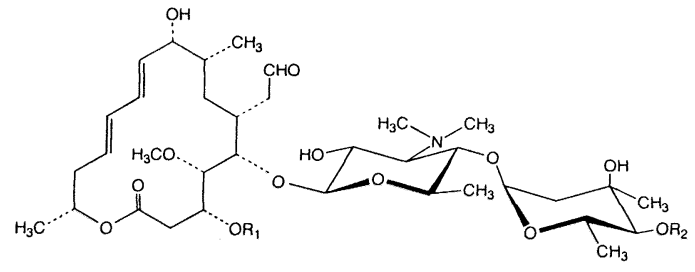

\begin{tabular}{llll} 
Leucomycin & $\mathrm{A}_{1}$ & \multicolumn{1}{c}{$\mathrm{R}_{1}$} & \multicolumn{1}{c}{$\mathrm{R}_{2}$} \\
Leucomycin & $\mathrm{H}_{3}$ & $-\mathrm{COCH}_{3}$ & $\left.-{ }^{-} \mathrm{COCH}_{2} \mathrm{CH}_{2} \mathrm{CH}_{3}\right)_{2}$ \\
(Josamycin) & & & \\
Leucomycin & $\mathrm{A}_{4}$ & $-\mathrm{COCH}_{3}$ & $-\mathrm{COCH}_{2} \mathrm{CH}_{2} \mathrm{CH}_{3}$ \\
Leucomycin & $\mathrm{A}_{5}$ & $-\mathrm{H}$ & $-\mathrm{COCH}_{2} \mathrm{CH}_{2} \mathrm{CH}_{3}$ \\
Leucomycin & $\mathrm{A}_{6}$ & $-\mathrm{COCH}_{3}$ & $-\mathrm{COCH}_{2} \mathrm{CH}_{3}$ \\
Leucomycin & $\mathrm{A}_{7}$ & $-\mathrm{H}$ & $-\mathrm{COCH}_{2} \mathrm{CH}_{3}$ \\
Leucomycin & $\mathrm{A}_{8}$ & $-\mathrm{COCH}_{3}$ & $-\mathrm{COCH}_{3}$ \\
Leucomycin & $\mathrm{C}_{9}$ & $-\mathrm{H}$ & $-\mathrm{COCH}_{3}$ \\
Leucomycin & $\mathrm{A}_{13}$ & $-\mathrm{H}$ & $-\mathrm{COCH}_{2} \mathrm{CH}_{2} \mathrm{CH}_{2} \mathrm{CH}_{2} \mathrm{CH}_{3}$
\end{tabular}

Fig. 1 Chemical structures of kitasamycin components

ロイコマイシン $\mathrm{A}_{5}, \mathrm{~A}_{3}$ 及び $\mathrm{A}_{1}$ の含有比率を求める方 法があるのみである．各ロイコマイシンの抗菌作用には 相違があることが知られており，医薬品製剤の品質を管 理する上からも，KT 中の各成分を正確に定量する方法 の開発が要求されている。一方，JM は MLs の中では 数少ない単一成分からなる抗生物質であるが，本抗生物 質は KT の構成成分の一つであるロイコマイシン $\mathrm{A}_{3}$ と 同一物質であることが明らかにされている4.

KT 及び JM を含め, 抗生物質の分析には一般に微生 物学的試験法が採用されている5).しかし，本法は選択 性に欠け，検出された抗菌性物質の特定や多成分からな る抗生物質の構成成分を定量することは困難である。 そ こで今回，高速液体クロマトグラフィー（HPLC）を用 いた KT 中の構成成分の一斉分析法を開発し，畜産物 中に残留する KT 及び JM の同時分析法に応用した.

\section{2 実験方法}

\section{$2 \cdot 1$ 試料及び試薬}

試料は埼玉県内で市販されている豚, 牛, 鶏の筋肉部 と肝臓及び埼玉県食肉センターより供与された豚じん臓 を用いた。

標準品: キタサマイシンは旭化成工業製, ジョサマイ シンは山之内製薬製を用いた。ロイコマイシン $\mathrm{A}_{1}$,

$\mathrm{A}_{4}, \mathrm{~A}_{9}, \mathrm{~A}_{13}$ 粗製標準品は旭化成工業から分与されたも のを使用した．標準溶液：標準品 $10 \mathrm{mg}$ を精ひょうし， メタノール $10 \mathrm{ml}$ に溶解して標準原液を調製し，適宜 蒸留水あるいは HPLC 移動相で希釈して標準溶液とし た。なお，標準原液は $5^{\circ} \mathrm{C}$ 以下で保存した。除タンパ

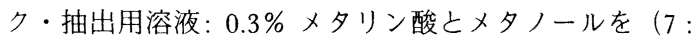

3）の割合に混合したものを用いた.

Bond Elut SCX カートリッジ (500 mg): Varian 製, カートリッジはあらかじめメタノール $5 \mathrm{ml}, 0.1 \mathrm{M} リ$ ン酸一カリウム溶液 $10 \mathrm{ml}$ でコンディショニングした 後使用した。その他の試薬はすべて特級品あるいは HPLC 用を使用した.

\section{$2 \cdot 2$ 装置及び測定条件}

高速液体クロマトグラフ：使用した HPLG 装置はす ベて島津製作所製であり，LC-6A に SPD-6A 型紫外分 光光度計を接続，検出波長は $232 \mathrm{~nm}$, 感度は 0.04 AUFS に設定し，データはクロマトパック C-R3A で処 理した。分析カラムは Puresil $5 \mathrm{C}_{18}(15 \mathrm{~cm} \times 4.6 \mathrm{~mm}$ i.d., Waters）を使用，移動相に $0.05 \mathrm{M}$ リン酸塩緩衝液 ( $\mathrm{pH} 2.5)$-アセトニトリル $(58: 42)$ を用い, 流量を 0.5 $\mathrm{ml} / \mathrm{min}$ に設定した。

自記分光光度計は日立製作所製 330 型, 冷却水循環 装置は東京理化器械製 CA-101 型，ホモジナイザーは日 音医理科器械製作所製ヒスコトロンを用いた。

\section{$2 \cdot 3$ 検量線の作成}

$\mathrm{KT}$ 及び $\mathrm{JM}$ の $0.5,1.0,2.0,5.0$ 及び $10 \mu \mathrm{g} / \mathrm{ml}$ の 溶液を調製し，その $10 \mu \mathrm{l}$ を HPLCに注入して得られ たクロマトグラムよりピーク面積を求め, 絶対検量線法 により検量線を作成した。

\section{$2 \cdot 4$ 試験溶液の調製}

試料 $5 \mathrm{~g}$ を採り，除タンパク・抽出用溶液 $100 \mathrm{ml}$ 加えて 2 分間ホモジナイズした後, 洰過補助剤ハイフ ロスーパーセルを厚さ約 $2 \mathrm{~mm}$ に敷いた吸引沪過器 （桐山漏斗）を用いて沪過した。なお，試料が肝藏及び じん臓の場合，沪過前にハイフロスーパーセル数 $\mathrm{g}$ を ホモジナイズ液に加え，軽く混合した後沪過した。冷却 水 (約 $\left.5^{\circ} \mathrm{C}\right)$ を循環したエバポレーターを用い, 沪液を $45^{\circ} \mathrm{C}$ の水浴中で約 $20 \mathrm{ml}$ に減圧濃縮した後, Bond Elut SCX カートリッジに負荷し, 蒸留水 $10 \mathrm{ml}$, 続いて 0.1 $\mathrm{M}$ リン酸二カリウム溶液 $5 \mathrm{ml}$ で洗浄後, メ夕ノール $10 \mathrm{ml}$ で溶出した。溶出液を減圧乾固した後，残留物を $0.05 \mathrm{M}$ リン酸一ナトリウム-アセトニトリル (7:3) 1 $\mathrm{ml}$ に溶解して試験溶液とし，この $10 \mu \mathrm{l}$ を HPLCに注 入した.

\section{$2 \cdot 5$ 微生物学的試験法}

試験菌として畜水産食品中の残留薬物検査にはん用さ れている中から, KT 及び JM に対して高い感受性を示 
す Micrococcus luteus ATCC 9341 を用いた。試験菌液及 び検査用平板培地の調製は公定法である “畜水産食品中 の残留物質検查法 第 1 集”6) に準拠して行った。抗菌 活性の測定はディスク法を用いた。

\section{3 結果及び考察}

\section{$3 \cdot 1$ HPLC 測定条件の検討}

HPLC を用いた KT の分析例は，ペリキュラータイ プの ODS カラムを用いた Omura ら ${ }^{1) 7}$ によるものがあ る.しかし，ペリキュラータイプの充てん剤は粒子径が 30 40 $\mu \mathrm{m}$ と大きく，炭素含有量も低いことから分離能 に乏しく，ロイコマイシン各成分の相互分離は達成され ておらず，各成分の定量に関しては全く言及されていな い。一方, JM は単一成分であり, 分析が容易であるこ とから，製剤や生体試料中の分析法が報告されてい $3^{8) \sim 12)}$. JM は KT 中に含まれる成分の一つであるロ イコマイシン $\mathrm{A}_{3}$ と同一物質であることから，KT の HPLC 測定条件を検討した.

まず，測定波長であるが，KTは $230 \mathrm{~nm}$ 付近に吸収 極大があることが知られている1). ここで，KTを HPLC 移動相に溶解し, 紫外部吸収スペクトルを測定 した結果, $232 \mathrm{~nm}$ に吸収極大が認められたので，測定 波長は $232 \mathrm{~nm}$ に設定した。続いて分離条件を検討し た．KT はほかの MLs と同様，構造中にアミノ糖を有 する塩基性化合物であることから，カラム充てん剤中の 残存シラノール基の影響を強く受けるものと思われる. そこで, 分離用カラムにはエンドキャッピング済みのも のを用い, リン酸塩緩衝液-アセトニトリルの組み合わ せから成る移動相により分離条件を検討した。検討した カラムの中では Puresil $5 \mathrm{C}_{18}$ が最もピーク形状に優れて いたので，分離用カラムには Puresil $5 \mathrm{C}_{18}$ を選んだ。

次に，移動相であるリン酸塩緩衝液-アセトニトリル の混合比, 塩濃度及び $\mathrm{pH}$ を変化させながら至適分離 条件を検討した，KT 中の各成分の保持比 $\left(k^{\prime}\right)$ はアセ トニトリルの含量が増加するに従い顕著に減少した。保 持時間とピーク形状を考慮して，アセトニトリルの含量 は $42 \%$ とした。この混合比でリン酸塩緩衝液中の塩濃 度を $0.1 \mathrm{M}$ まで変え, 各成分の $k$ 及びピーク形状に及 ぼす影響を調べると，リン酸塩を含まない場合，各成分 はカラムに強く保持されブロードなピークを与え, 塩濃 度が高くなるに従い優れたピーク形状を示した。リン酸 塩を含まない水-アセトニトリル系の移動相の $\mathrm{pH}$ は 7 前後であり，この $\mathrm{pH}$ では充てん剤中の残存シラノー ル基は解離して弱陽イオン交換基 $\left(\mathrm{SiOH}^{-}\right)$となって おり，塩基性化合物である $\mathrm{KT}$ が強く保持されたもの
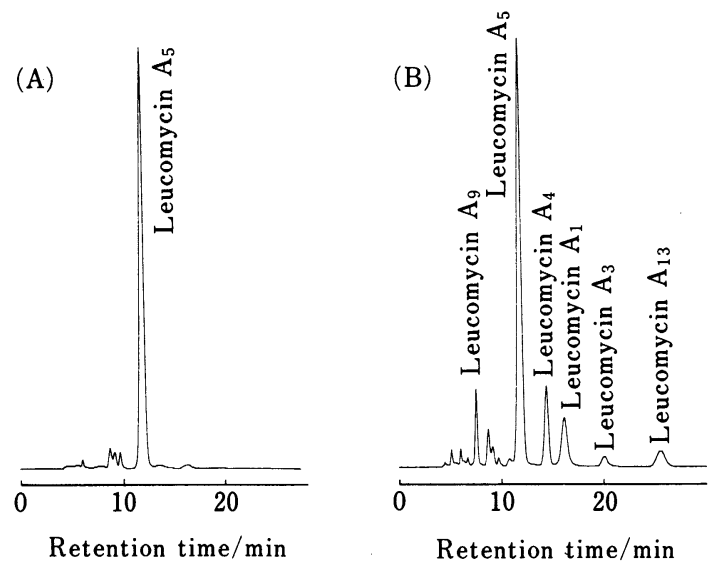

Fig. 2 Typical chromatograms of current reference preparations (A) and pharmaceutical preparations of kitasamycin (B)

LC conditions: column, Puresil $5 \mathrm{C}_{18} \quad(150 \times 4.6$ $\mathrm{mm})$; mobile phase, $0.05 \mathrm{M}$ phosphate buffer $(\mathrm{pH}$ 2.5 )-acetonitrile (58:42); flow-rate, $0.5 \mathrm{ml} / \mathrm{min}$; detection, UV $232 \mathrm{~nm}$

と考えられる．前述したとおり，塩濃度が高くなるに従 い優れたピーク形状を示したが，力ラムの劣化を考慮す ると塩濃度は低いほうが好ましく, $0.05 \mathrm{M}$ でも十分優 れたピーク形状が得られたため, 塩濃度は $0.05 \mathrm{M}$ とし た. 次に，リン酸塩緩衝液の $\mathrm{pH}$ の影響を調べると， $\mathrm{pH}$ が低いほど各成分とも $k$ ' は小さくなり, ピーク形 状に優れたクロマトグラムが得られた。これは $\mathrm{pH}$ が 低いほよ゙，構造中のアミノ糖がイオン性をおび，親水性 が増すこと及び残存するシラノール基の解離が抑制され るためと考えられる.

以上の結果から, 保持時間, 相互分離, ピーク形状及 びカラムの劣化などを考慮して, 移動相には $0.05 \mathrm{M}$ リ ン酸塩緩衝液（pH 2.5）-アセトニトリル（58：42）を用 いた。この HPLC 条件によって得られた KT 製剤のク ロマトグラムを Fig. 2 に示す.一般的に MLs は酸性 水溶液中では不安定 ${ }^{13)}$ であるとされているため, 移動 相中での KT の安定性（室温， $10 \mu \mathrm{g} / \mathrm{ml}$ ) を調べたと ころ，24 時間経過後においても分解はほとんど認めら れなかった。 なお，クロマトグラム上のピーク成分の帰 属は, $\mathrm{KT}$ 標準品（ロイコマイシン $\mathrm{A}_{5}$ ), JM 標準品 (ロイコマイシン $\mathrm{A}_{3}$ ), 及びロイコマイシン $\mathrm{A}_{1}, \mathrm{~A}_{4}$, $\mathrm{A}_{9} ， \mathrm{~A}_{13}$ 粗製標準品を用いて行った.

\section{$3 \cdot 2$ 市販製剤の分析}

$\mathrm{KT}$ の構成成分である各ロイコマイシンは, 化学構造 
Table 1 Determination of leucomycin (LM) components in kitasamycin preparations

\begin{tabular}{|c|c|c|c|c|c|c|c|}
\hline \multirow{2}{*}{ Sample } & \multicolumn{7}{|c|}{ Composition, \% } \\
\hline & LM $\mathrm{A}_{9}$ & $\mathrm{LM} \mathrm{A}_{5}$ & $\mathrm{LM} \mathrm{A}_{4}$ & $\mathrm{LM} \mathrm{A}$ & $\mathrm{LM} \mathrm{A}_{3}$ & $\mathrm{LM} \mathrm{A} \mathrm{A}_{13}$ & Others \\
\hline 1 & 5.2 & 55.8 & 10.5 & 6.3 & 1.7 & 5.5 & 15.0 \\
\hline 2 & 5.3 & 54.4 & 10.4 & 6.5 & 1.6 & 5.0 & 16.8 \\
\hline 3 & 4.5 & 56.6 & 10.7 & 7.2 & 1.7 & 6.0 & 13.3 \\
\hline 4 & 3.6 & 45.7 & 18.5 & 9.3 & 3.5 & 6.3 & 13.1 \\
\hline 5 & 6.0 & 57.5 & 10.7 & 9.8 & 2.2 & 4.7 & 9.1 \\
\hline Reference 1 & _b) & 90.2 & - & 2.5 & - & - & 7.3 \\
\hline Reference $2^{\text {a) }}$ & 18.5 & 29.0 & 8.2 & 12.4 & 3.0 & 1.0 & 27.9 \\
\hline Reference $3^{\text {a) }}$ & 19.5 & 25.9 & 7.3 & 11.0 & 2.8 & 0.5 & 33.0 \\
\hline
\end{tabular}

a) These were old reference preparations of kitasamycin. b) Not detected $(<0.1 \%)$

が極めて類似しており，吸収極大波長である $232 \mathrm{~nm} に$ おける分子吸光係数はほぼ同じであることが報告されて (る2). 又, 各ロイコマイシンの分子量もほぼ等しいこ とから, $\mathrm{KT}$ 中のロイコマイシン $\mathrm{A}_{1}, \mathrm{~A}_{3} \sim \mathrm{A}_{9}, \mathrm{~A}_{13}$ 等 の定量は, クロマトグラム上の各成分のピーク面積をも って評価した．本 HPLC 条件を用いて KT 標準品及び 市販製剤を分析した結果を Table 1 に示す. 最近製造 された KT 標準品ではロイコマイシン $\mathrm{A}_{5}$ が $90 \%$ を占 めていたが, 約 10 年前に製造された標準品では, $\mathrm{A}_{5}$ の含有量は $30 \%$ 以下であった. 一方, 現在流通してい る $\mathrm{KT}$ 製剤は, $\mathrm{KT}$ 標準品ほど分離・精製されておら ず，ロイコマイシン $\mathrm{A}_{5}$ の含有量は約 $50 \%$ であった. この分析結果は, 先に示した省令 ${ }^{3)}$ 中の KT 原体の成分 規格 ( $\mathrm{A}_{5}$ 含有量: 40 ～70\%）を満足するものである. ロイコマイシン各成分は乾燥状態では安定性が高いこと が知られている ${ }^{13)}$. 又, KT 標準品は, 1990 年に日本 抗生物質医薬品基準 ${ }^{14)}$ が大幅に改正される前までは複 数成分の混合物であったが, 改正後にはロイコマイシン $\mathrm{A}_{5}$ 単一成分とされた. 以上のことから, $\mathrm{KT}$ 標準品の 成分組成の相違は生産菌株や分離・精製の進歩に由来す るものと思われる。

KT のように数多くの成分から構成されている場合, 各成分をどのように評価するかが問題となるが, 残留濃 度が比較的高く, 各成分を検出・定量することが可能な 場合は各成分を評価することが好ましい。しかし, 実際 に畜産物中に残留する $\mathrm{KT}$ 濃度は微量であることから, $\mathrm{KT}$ の主成分である $50 \%$ 前後を占めるロイコマイシン $\mathrm{A}_{5}$ の評価をもって残留 $\mathrm{KT}$ とすることが実際的な対応 策と考える. 次に, JM の標準品及び製剤を分析した結 果を Table 2 に示す. 標準品及び製剤とも JM が $90 \%$ 前後とほとんどを占めていたが，ロイコマイシン $\mathrm{A}_{4}$ な どの他の成分も含まれていた．しかし，他の成分の含有
Table 2 Determination of josamycin components in josamycin preparations

\begin{tabular}{cccc}
\hline \multirow{2}{*}{ Sample } & \multicolumn{3}{c}{ Composition, \% } \\
\cline { 2 - 4 } & Josamycin(LM A A $\left._{5}\right)$ & LM A $_{4}$ & Others \\
\hline 1 & 87.8 & 5.8 & 6.4 \\
2 & 86.9 & 6.9 & 6.2 \\
3 & 87.4 & 6.3 & 6.3 \\
Reference & 94.3 & 2.2 & 3.5 \\
\hline
\end{tabular}

量が極めて少ないことから, 残留分析においては主成分 である JM の定量をもって残留量と考えられる.

\section{$3 \cdot 3$ 前処理法の検㯆}

Skinner らは ${ }^{9)}$, 血清中の JM のクリーンアップに $\mathrm{C}_{18}$ カートリッジを用いている. そこで, 畜産物中の $\mathrm{KT}$ 及び JM のクリーンアップに $\mathrm{C}_{18}$ カートリッジが 応用できるか検討した。なお，前述したとおり，KTの 残留分析においては主成分であるロイコマイシン $\mathrm{A}_{5}$ を 指標成分とすることが適切であることから，ここでは口 イコマイシン $\mathrm{A}_{5}$ を $90 \%$ 含有する $\mathrm{KT}$ 標準品を用い た. KT 及び JM は, 脂溶性の高い化合物であるこよか ら, $\mathrm{C}_{18}$ カートリッジに強く保持された. しかし, 血清 に比べ食肉, 肝臓及びじん蔵等は多量のタンパク質, 脂 質, アミノ酸などのきょう雑成分を含んでおり， $\mathrm{C}_{18}$ カートリッジによるクリーンアップ法ではきょう雑成分 を十分除去することができなかった.

MLs は脂溶性が極めて高く，かつ塩基性化合物であ ることから, 著者らは食肉中のスピラマイシン ${ }^{15)} の ク$ リーンアップに液-液分配法を採用した。同様に Nagata ら ${ }^{16)}$ は, 鶏肉中のスピラマイシンを, Keng ら ${ }^{17)}$ は, 牛 組織中のチロシンのクリーンアップに液-液分配法を, 


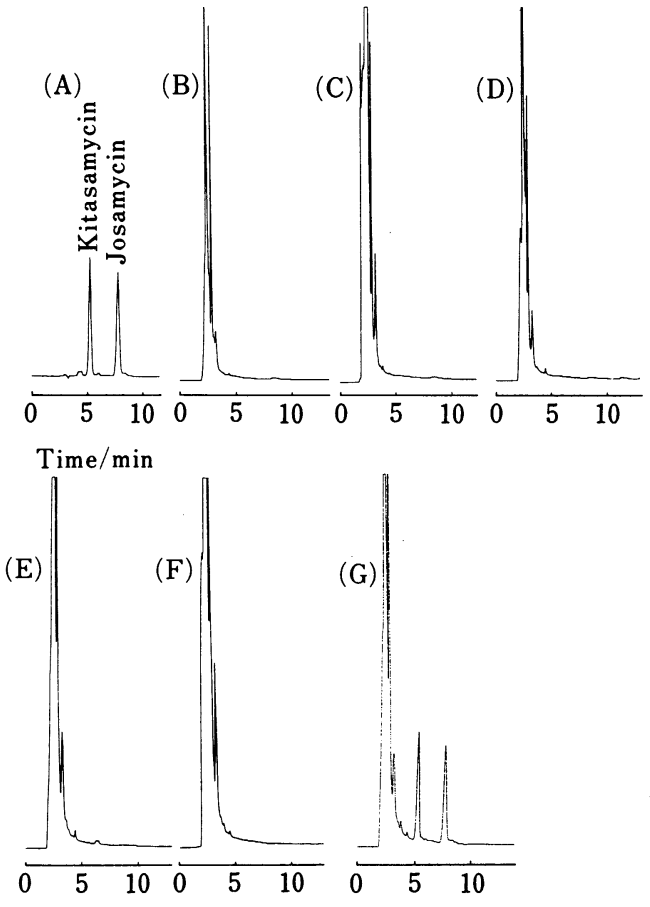

Fig. 3 Typical chromatograms of (A) standard mixture (both drugs, $50 \mathrm{ng}$ ), (B) blank chicken muscle extract, (C) blank swine muscle extract, (D) blank cattle muscle extract, (E) blank chicken liver extract, (F) blank swine liver extract and (G) extract of swine muscle fortified with $1.0 \mu \mathrm{g} / \mathrm{g}$ of both drugs LC conditions: mobile phase, $0.05 \mathrm{M}$ phosphate buffer ( $\mathrm{pH} 2.5)$-acetonitrile $(52: 48)$. Other conditions as in Fig. 2.

Okada らは18), 豚組織中のセデカマイシンのクリーン アップに液-液分配法とカラムクロマトグラフィーを採 用している。しかし, ジクロロメタンを用いた液-液分 配法によるクリーンアップ法では, 肝臓及びじん蔵を試 料に用いたとき, エマルションが形成され, クリーンア ップ法としては不適当であった.

$\mathrm{KT}$ 及び JM は構造中にアミノ糖を含む塩基性化合物 であるので, 陽イオン交換相が充てんされているカート リッジを用いたクリーンアップ法を検討した， KT 及び $\mathrm{JM}$ は脂溶性と塩基性を有する化合物であることから, カートリッジには陽イオン性と脂溶性の両方の性質を示 すイオン交換相（プロピルベンゼンスルホニル基）が充 てんされている Bond Elut SGX を採用した. まず, 酸 性条件下 (濃縮抽出液の $\mathrm{pH}$ は 4 前後) で $\mathrm{KT}$ 及び $\mathrm{JM}$ をカートリッジに保持させた。. 次に, $\mathrm{KT}$ 及び JM
Table 3 Recoveries of kitasamycin and josamycin from animal tissues

\begin{tabular}{lcc}
\hline \multirow{1}{*}{ Sample } & \multicolumn{2}{c}{ Recovery, \% } \\
\cline { 2 - 3 } & Kitasamycin & Josamycin \\
\hline Chicken muscle & $82.2 \pm 2.7$ & $82.5 \pm 2.3$ \\
Chicken liver & $79.0 \pm 4.7$ & $79.7 \pm 5.0$ \\
Swine muscle & $88.4 \pm 3.0$ & $89.7 \pm 2.7$ \\
Swine liver & $76.8 \pm 5.9$ & $77.3 \pm 6.1$ \\
Swine kidney & $78.0 \pm 4.5$ & $77.0 \pm 3.9$ \\
Cattle muscle & $90.2 \pm 1.7$ & $91.5 \pm 2.1$ \\
Cattle liver & $81.0 \pm 5.7$ & $83.2 \pm 4.8$ \\
\hline
\end{tabular}

Values are mean \pm S.D. $(n=5)$. Samples were spiked with $1.0 \mu \mathrm{g} / \mathrm{g}$ both drugs.

のカートリッジからの溶出はリン酸二カリウムでカート リッジを洗浄することにより KT 及び JM を中性化し， その後メタノールで溶出した．本法を用いることによ り, Fig. 3 に示すとおりきょう雑物質の影響のない試験 溶液を調製できた。なお，前記したとおり，KTにあっ ては, 主成分であるロイコマイシン $\mathrm{A}_{5}$ を残留性を評価 する指標成分とした。このことから，迅速かつ高感度な 分析を目的に, 移動相中のアセトニトリル含量を製剤分 析時より $6 \%$ 高くして $48 \%$ とすることとした.

\section{$3 \cdot 4$ 添加回収実験}

市販の鶏, 豚, 牛の筋肉部と肝臓及び豚じん臓に KT 及び JM を $1 \mu \mathrm{g} / \mathrm{g}$ の濃度に添加し, 回収率を求めた.

Table 3 に示すとおり, 各試料に対する回収率はいずれ も平均で $75 \%$ 以上であった．標準偏差（SD）はいずれ の検体も $10 \%$ 以内であり, 残留分析法として満足でき る值が得られた ${ }^{19)}$. なお, 本法による検出限界は, KT 及び $\mathrm{JM}$ とも $0.05 \mu \mathrm{g} / \mathrm{g}(S / N=3)$ であった。

\section{$3 \cdot 5$ 微生物学的試験法との相関}

微生物に対する抗菌活性を直接利用した試験法が公定 法6) として採用されている.そこで，今回確立した HPLC 法の妥当性を評価するため, 公定法である微生 物学的試験法との相関性を調べた。

$\mathrm{KT}$ 標準品を添加した豚肉試料について，本法により 定量した值と，試験菌として Micrococcus luteus ATCC 9341 を用いた微生物学的試験法により得られた定量値 との相関性を求めた。微生物学的試験法には簡易なディ スク法を用い, 再現性を考慮して各試料につき 3 回測 定を行い，その平均値を定量値とした．Fig. 4 に示した とおり, 両者の間には相関係数 $r=0.98$ と高い相関が得 


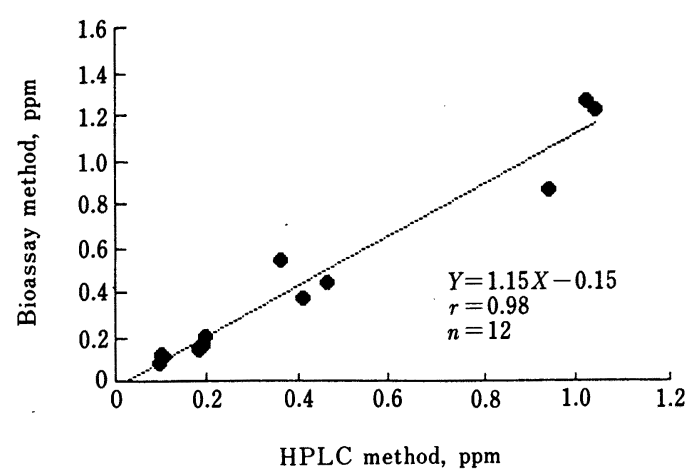

Fig. 4 Correlation between HPLC and bioassay methods for kitasamycin in swine muscle

られた，同様にJMについても微生物学的試験法との 間に, 相関係数 $r=0.97$ と高い相関が得られた. 更に, 本法の検出感度は従来法である微生物学的試験法に比心

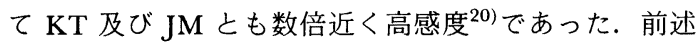
したとおり, 微生物学的試験法では検出された抗菌性物 質を特定することが困難である，しかし，本 HPLC 法 を用いることにより，畜産食品中に残留する薬物が KT あるいは JMであるかを迅速に特定できる.

本研究では多成分からなる KT 及び KT の構成成分 の一種である JM の製剤分析法を確立し, 更に畜産物 中の残留分析法に応用した．KT の残留分析では，主成 分であるロイコマイシン $\mathrm{A}_{5}$ を残留性を評価する指標成 分とすることが実際的な対応策であると考えた。本法に よる定量值は公定法である微生物学的試験法と高い相関 性が認められ，かつ感度及び選択性にも優れていること から，KT 及び JM の残留分析法として日常検査に利用 することが期待できる.

\section{文献}

1）堀江正一, 中澤裕之: 食品衛生学雑誌, 36, 329 (1995).

2) S. Omura, A. Nakagawa: J. Antibiot., 28, 401 (1975).

3）“飼料及び飼料添加物の成分規格に関する省令”: 1976 年 7 月 24 日, 農林水産省令第 35 号.

4) S. Omura, Y. Hironaka, T. Hata: J. Antibiot., 23, $511(1970)$.

5）畜産生物科学安全研究所編: “畜水産食品の薬物 残留とその分析法”, p. 97 (1994), (近代出版).

6）厚生省環境衛生局乳肉衛生課編: “畜水産食品中 の残留物質検査法 第 1 集”, (1981).

7) S. Omura, Y. Suzuki, A. Nakagawa, T. Hata: J. Antibiot., 26, 794 (1973).

8) K. Rader, A. Wildfeuer, A. Schwerdass, H. Laufen: J. Chromatogr., 344, 416 (1985).

9) M. Skinner, I. Kanfer: J. Chromatogr., 459, 261 (1988).

10) C. Stubbs, M. F. Skinner, I. Kanfer: Chromatographia, 29, 31 (1990).

11) M. Tod, O. Biarez, P. Nicolas, O. Petitjean: J. Chromatogr., 575, 171 (1992).

12) P. Leroy, D. Decolin, A. Nicolas, P. Archimbault: Analyst (London), 119, 2743 (1994).

13）二宮幾代治 “動物の抗生物質”, p. 307 (1987), (養賢堂)

14）“日本抗生物質医薬品基準”：1990 年 3 月 31 日, 厚生省告示第 87 号.

15）堀江正一, 能勢憲英, 志田保夫, 中澤裕之: 分析 化学 (Bunseki Kagaku), 35, 219 (1986).

16) T. Nagata, M. Saeki: J. Assoc. Off. Anal. Chem., 69, 644 (1986).

17) L. J. Keng, J. O. Boison: J. Liq. Chromatogr., 15, 2025 (1992).

18) J. Okada, S. Kondo: J. Assoc. Off. Anal. Chem., 70, 818 (1987).

19）農林水産省畜産局編：“動物用医薬品の GLP 基 準及び毒性試験等ガイドライン解説”, p. 88 (1988)，(日本動物薬事協会).

20）神保勝彦, 片岡 潤, 小久保弥太郎, 小沼博隆, 近藤房生：食品衛生学雑誌, 36, 525 (1995).

\section{要旨}

高速液体クロマトグラフィー（HPLC）を用いた食肉中のマクロライド系抗生物質（MLs），キタサ マイシン (KT) 及びジョサマイシン ( JM) の簡易かつ迅速な残留分析法を検討した。 MLsは一般に 構造が類似した複数の成分から構成されており，KTはロイコマイシン $\mathrm{A}_{1}, \mathrm{~A}_{3} \sim \mathrm{A}_{9}$ 等の多成分からな る混合物である。一方, JM は KT を構成するロイコマイシン $\mathrm{A}_{3}$ と同一物質である. $\mathrm{KT}$ の分離に は, カラムに Puresil $5 \mathrm{C}_{18}(150 \times 4.6 \mathrm{~mm})$, 移動相には $0.05 \mathrm{M}$ リン酸塩緩衝液 $(\mathrm{pH} 2.5)$ アアセトニト リル (58: 42) を用い, 流量は毎分 $0.5 \mathrm{ml}$, 測定波長は $232 \mathrm{~nm}$ とした. 試料の前処理法は, $0.3 \%$ メ タリン酸-メタノール (7:3) で除タンパクと同時に抽出し, 陽イオン交換樹脂が充てんされた Bond Elut SCX カートリッジ $(500 \mathrm{mg})$ でクリーンアップを行った. 本法における鶏肉, 鶏肝臓, 豚肉, 豚 肝藏, 牛肉, 牛肝蔵等に対する添加回収率は $1 \mu \mathrm{g} / \mathrm{g}$ の添加で $76.8 \sim 91.5 \%$, 検出限界は $0.05 \mu \mathrm{g} / \mathrm{g}$ で あった。 